\title{
UJI SPEKTRUM CAHAYA ECENG GONDOK (EICHORNIA CRASSIPES) SEBAGAI ABSORBER PADA DYE SENSITIZED SOLAR CELL (DSSC)
}

\author{
Ice Trianiza \\ Program Studi Teknik Industri, Fakultas Teknik \\ Universitas Islam Kalimantan Muhammad Arsyad Al Banjari \\ Jl. Adhyaksa No. 2 Kayu Tangi Banjarmasin 70123 \\ e-mail:ice_trianiza@uniska-bjm.ac.id
}

\begin{abstract}
Abstrak - Telah dilakukan penelitian mengenai uji spectrum eceng gondok (eichornia crassipes) sebagai absorber pada DSSC. Penelitian ini bertujuan untuk mengetahui nilai absorber pada dye eceng gondok. Pengujian dilakukan menggunakan lampu halogen dengan jarak sel $5 \mathrm{~cm}$ dari lampu. DSSC didapatkan nilai absorber dye menggunakan instrument UV-VIS pada panjang gelombang $800 \mathrm{~nm}$ adalah 2,8 . Sehingga layak di pertimbangkan untuk dilakukan pengembangan lanjutan .
\end{abstract}

Kata kunci - Dye Sensitized Solar Cell (DSSC), eceng gondok (eichornia crassipes), Sel Surya

\section{PENDAhuluan}

$\mathrm{E}$ Ceng gondok merupakan tanaman air yang poulasinya sangat besar di Kalimantan Selatan, pada pemanfaatannya selama ini banyak digunakan sebagai pewarna tekstil alami karena menurut penelitian eceng gondok memiliki zat pewarna alami flovanoid yang mampu menyerap cahaya matahari. Pada penelitian penulis sebelumnya telah diteliti bagaimana pengaplikasian zat peawarna alam pada Dye sensitized Solar Cell (DSSC). Penelitian ini bertujuan untuk Membuat prototipe DSSC yang dapat mengkonversi energi cahaya menjadi energi listrik dengan $\mathrm{TiO} 2$ sebagai bahan semikonduktor menggunakan hasil ekstraksi eceng gondok pada prototipe DSSC. Pembuatan DSSC (Dye-Sensitized Solar Cell) dapat digunakan sebagai studi awal dalam perkembangan sel surya alternatif agar dapat dilakukan penelitian lebih lanjut sehingga menghasilkan sel surya alternatif yang lebih baik untuk kedepannya serta mampu memberikan ide atau gagasan dalam pembuatan sel surya alternatif yang baik dan dengan biaya yang terjangkau.

\section{TINJAUAN PUSTAKA}

\section{A. Dye-Sensitized Solar Cell}

Dye-Sensitized Solar Cell (DSSC), sejak pertama kali ditemukan oleh profesor Michael Gretzel pada tahun 1991, telah menjadi salah satu topik penelitian yang dilakukan intensif oleh peneliti di seluruh dunia. DSSC bahan disebut juga terobosan pertama dalam teknologi sel surya sejak sel surya silikon [4].

Berbeda dengan sel surya konvensional, DSSC adalah sel sutya fotoelektrokimia sehingga menggunakan elektrolit sebagai medium transport muatan. Selain elektrolit, DSSC terbagi menjadi beberapa bagian yang terdiri dari nanokristal pori $\mathrm{TiO}_{2}$, molekul dye yang teradsorpsi di permukaan $\mathrm{TiO}_{2}$ dan katalis yang semuanya dideposisi diantara dua kaca konduktif.

Pada bagian atas sel surya merupakan glass yang sudah dilapisi oleh TCO (Transparent Conducting Oxide), yang berfungsi sebagai elektroda dan counter-elektroda. Pada TCO counter-elektroda dilapisi katalis untuk mempercepat reaksi redoks dengan elektrolit. Pasangan redoks yang umumnya dipakai yaitu I-// $\mathrm{I}^{3-}$ (iodide/triiodide).

Pada permukaan elektroda dilapisi oleh nanokristal pori $\mathrm{TiO}_{2}$ yang mana dye teradopsi di $\mathrm{TiO}_{2}$. Jumlah pori yang lebih banyak dengan pengaturannya dalam struktur nano, memungkinkan dye yang teradsorpsi lebih banyak menghasilkan proses absorbsi cahaya yang lebih efisien. Dye yang umumnya digunakan yaitu jenis ruthenium complex.

\section{B. Prinsip Kerja Dye-Sensitized Solar Cell}

Foton (sinar matahari) yang terabsorbsi oleh dye akan mengalami eksitasi elektron pada dye. Kejadian ini memberikan energi yang cukup kepada elektron untuk pindah menuju conduction band dari $\mathrm{TiO}_{2}$. Akibatnya elektron mengalir menuju elektroda, rangkaian listrik sampai Counter elektroda. Elektrolit membawa elektron-elektron kembali ke dye yang berasal dari counter elektroda (CE).

Dye yang digunakan pada DSSC umumnya berupa dye sintetik Ruthenium kompleks. Ruthenium kompleks memiliki kemampuan berikatan baik dengan semikonduktor karena memiliki ikatan carboxylate. Ikatan tersebut memberikan efek elektron yang mengalir baik tanpa harus melakukan lompatan dan hambatan dalam proses pengalirannya. Awal penemuan DSSC oleh Michael Gratzel, digunakan dye sintetik ruthenium compleks tipe $\mathrm{N} 3$ yang menghasilkan efisiensi konversi energi sebesar 7,9\%. 


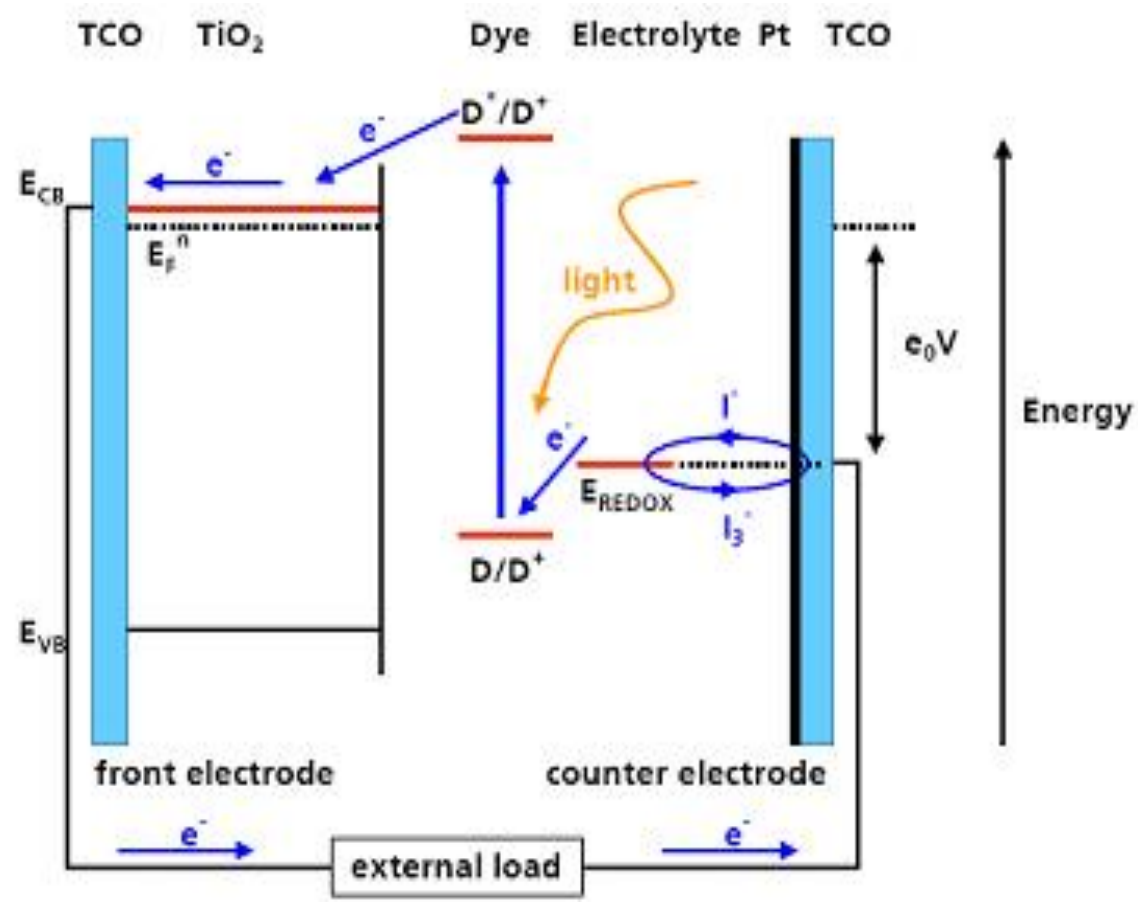

Gambar 1. Skema Kerja dari DSSC

Pada dasarnya prinsip kerja dari DSSC merupakan reaksi dari transfer elektron. Proses pertama dimulai dengan terjadinya eksitasi elektron pada molekul dye akibat absorbsi foton. Elektron tereksitasi dari groundstate (D) ke excited state $\left(\mathrm{D}^{*}\right)$.

$$
\mathrm{D}+\mathrm{e}^{-} \quad \rightarrow \quad \mathrm{D}^{*}
$$

Elektron dari excited state kemudian langsung terinjeksi menuju conduction band $\left(\mathrm{E}_{\mathrm{CB}}\right)$ titania sehingga molekul dye teroksidasi $\left(\mathrm{D}^{+}\right)$. Dengan adanya donor elektron oleh elektrolit $\left(\mathrm{I}^{-}\right)$maka molekul dye kembali ke keadaan awalnya (ground state) dan mencegah penangkapan kembali elektron oleh dye yang teroksidasi.

$$
2 \mathrm{D}^{+}+3 \mathrm{e}^{-} \rightarrow \mathrm{I}_{3}{ }^{-}+2 \mathrm{D}
$$

Setelah mencapai elektroda TCO, elektron mengalir menuju counter-elektroda melalui rangkain eksternal. Dengan adanya katalis pada counter-elektroda, elektron diterima oleh elektrolit sehingga hole yang terbentuk pada elektrolit $\left(\mathrm{I}_{3}{ }^{-}\right)$, akibat donor elektron pada proses sebelumnya, berekombinasi dengan elektron membentuk iodide ( $\left.\mathrm{I}^{-}\right)$.

\section{$\mathrm{I}_{3}{ }^{-}+2 \mathrm{e}^{-} \quad \rightarrow \quad 3 \mathrm{I}^{-}$}

Iodide ini digunakan untuk mendonor elektron kepada dye yang teroksidasi, sehingga terbentuk suatu siklus transport elektron. Dengan siklus ini terjadi konversi langsung dari cahaya matahari menjadi listrik.

\section{Deskripsi Eceng Gondok}

Eceng gondok (Eichornia crassipes) merupakan salah satu gulma yang banyak ditemui di perairan dengan arus tenang. Eceng gondok ini dapat mengapung di permukaan air karena memiliki daun yang tebal dan menggelembung. Eceng gondok dikategorikan sebagai gulma karena menyebabkan gangguan antara lain eceng gondok dapat menyebar di area yang luas dan menutupi permukaan air karena tingkat pertumbuhannya yang sangat cepat sehingga mengganggu ekosistem di bawahnya dan mengakibatkan berkurangnya kandungan oksigen terlarut dalam air. Gangguan lain yang ditimbulkan berupa pendangkalan akibat eceng gondok yang mati dan mengendap di dasar badan air sehingga semakin lama perairan menjadi dangkal selain itu juga mengurangi keindahan [2].

Pengendalian pertumbuhan eceng gondok perlu dilakukan agar tidak mengganggu ekosistem kehidupan air. Pengendalian eceng gondok dapat dilakukan dengan cara memanfaatkannya menjadi sepatu, taplak meja, dan pewarna alami. Penulis memilih eceng gondok sebagai zat warna alam karena memiliki pertumbuhan yang sangat cepat serta mengandung tanin dan flavonoid [6].

Penelitian Rorong dan Suryanto menunjukkan bahwa kandungan tanin tertinggi dalam eceng gondok terdapat di bagian helai daunnya. Zat warna alam yang banyak mengandung tanin akan menghasilkan warna coklat [5].

Pengambilan tanin dari suatu tumbuhan dapat dilakukan dengan cara ekstraksi. Salah satu faktor yang berpengaruh pada proses ekstraksi adalah jenis pelarut yang digunakan. Tanin termasuk golongan senyawa polifenol yang bersifat polar, dapat larut dalam gliserol, alkohol dan hidroalkoholik, air dan aseton, tetapi tidak larut dalam kloroform, petroleum eter dan benzena. 


\section{METODOLOGI PERCOBAAN}

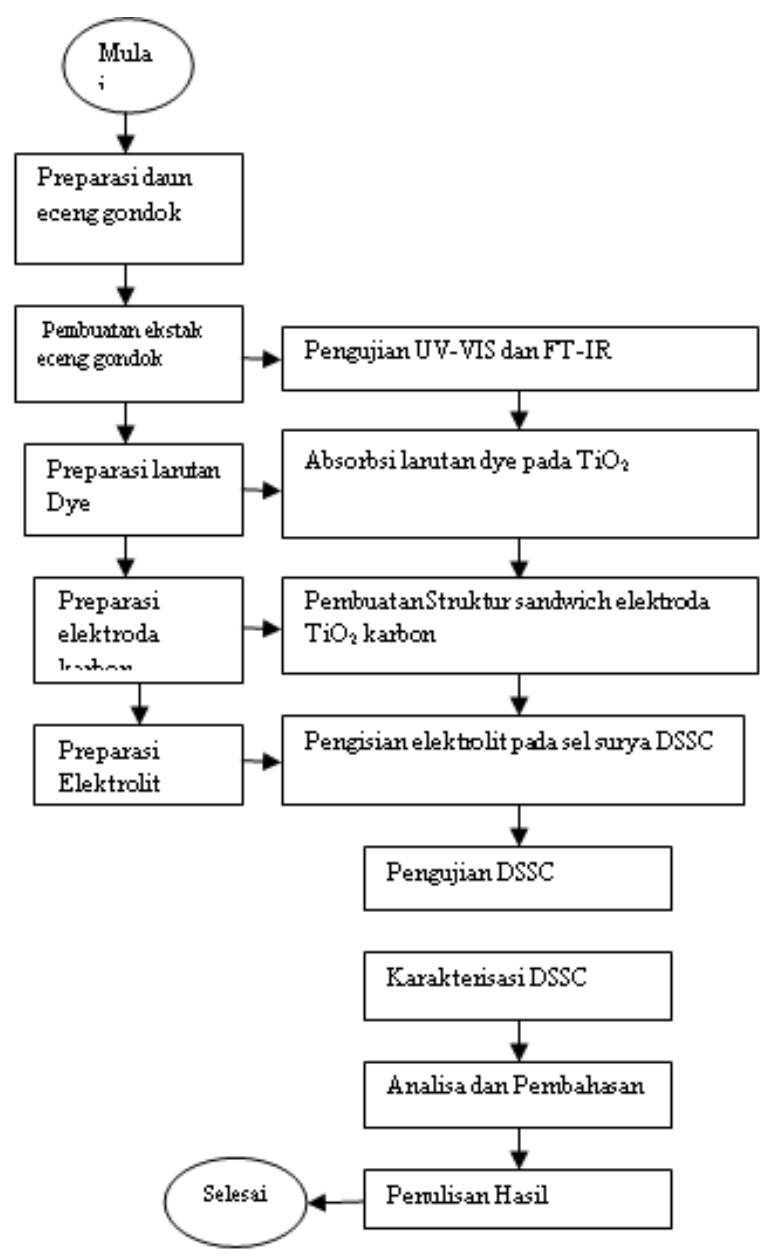

Gambar 2. Diagram Alir Penelitian DSSC Eceng Gondok

Lokasi Penelitian yang kami ambil untuk pengambilan sampel adalah kawasan jembatan antasari dengan lokasi proses pengolahan di kampus UNISKA MAB. Waktu penelitian yang kami lakukan adalah bulan Desember 2019Februari 2020.

Pewarna yang digunakan dalam penelitian ini adalah eceng gondok. Penelitian yang dilakukan terdiri dari beberapa tahap yaitu ektraksi zat warna alam eceng gondok yaitu dengan mengambil ekstrak eceng gondok dengan Daun yang dipilih adalah daun yang sudah cukup tua (daun yang sudah tidak menggulung di tangkainya). Pencucian daun bertujuan agar kotoran-kotoran yang terdapat pada daun hilang sehingga tidak tercampur pada larutan ekstraksi. Pengovenan dilakukan pada suhu $80 \mathrm{oC}$ selama 5 jam sehingga berat akhir mencapai $\pm 25 \%$ berat semula (daun menjadi kering). Pengovenan ini dilakukan dengan tujuan mengurangi kadar air yang terkandung dalam helai daun (Samanta dan Konar, 2014). Pengeringan juga bertujuan untuk memudahkan saat proses ekstraksi. Untuk menguji daya serap dari ekstrak eceng gondok yaitu dengan menggunakan spektrofotometer UV-VIS

\section{ANALISA DATA DAN PEMBAHASAN}

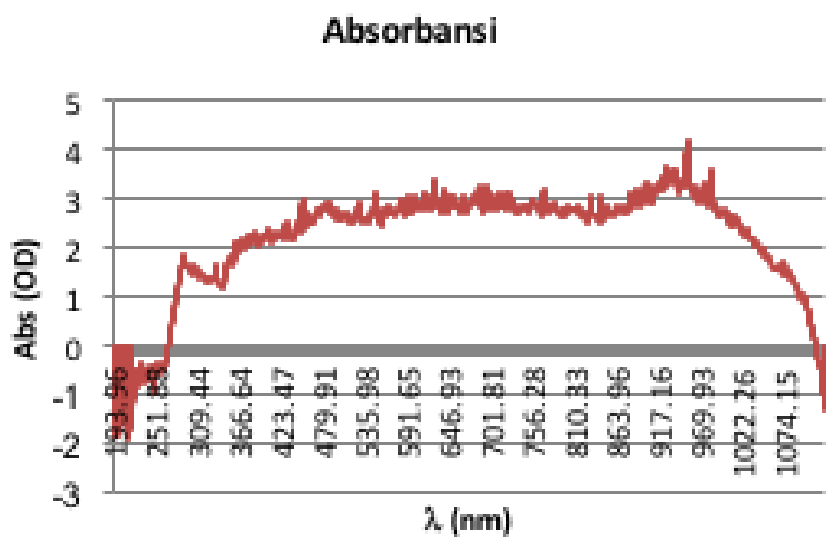

Gambar 3. Grafik Hubungan Kemampuan Absorbansi Ekstraksi Eceng Gondok Terhadap Panjang Gelombang

Dari hasil uji spektrofotometer uv-vis menggunakan spektrofotometer Beckman DU-7500 pada dye buah eceng gondok dapat dilihat perbedaan absorbansi yang didapat dengan pengambilan rentang 300-800nm, ukuran ini ditentukan berdasarkan panjang gelombang cahaya untuk radiasi ultraviolet dengan rentang 300-800nm. Untuk data absorbansi pada kulit buah eceng gondok di dapatkan cahaya tampak dimulai dari panjang gelombang $335 \mathrm{~nm}-775 \mathrm{~nm}$ dengan rentang penyerapan 2 - 1,902. Adapun absorbansi paling tinggi terdapat pada panjang gelombang $800 \mathrm{~nm}$ dengan absorbansi 2,8 dapat dilihat dari grafik diatas bahwa absorbansi lebih stabil dengan mana hasil pengolahan dye ini berpengaruh terhadap performa DSSC

\section{KESIMPULAN}

Dari ini maka didapatkan beberapa kesimpulan antara lain:

1. Sel DSSC yang telah dibuat dengan $\mathrm{TiO}_{2}$ sebagai bahan semi konduktor dan ekstraksi eceng gondok sebagai dye sensitizer terbukti berhasil mengkonversi energi surya menjadi energi listrik. Dibuktikan dengan adanya tegangan dan arus yang ditimbulkan dari sel DSSC yang telah dibuat.

2. DSSC telah diuji efisiensinya dan sudah didapatkan juga grafik hubungan I-V. Nilai eabsorbansi paling tinggi yang didapatkan adalah 2,8 pada panjang gelombang $800 \mathrm{~nm}$.

\section{DAFTAR PUSTAKA}

[1] Lang, KR (2003), The Cambridge Guid to The Solar System, Cambridge: Cambridge University Press, hlm. 183, ISBN 97805218130668

[2] 25 O'regan dan Gratzel, M. "A Low-Cost, High Efficiency Solar Cell Based On Dye-Sensitized Colloidal Tio2 Films". Nature Vol. 353. Issue 6346, 737. 1991.

[3] Septina, Wilman. Dkk, (2007), "Pembuatan Prototipe Solar Cell Murah dengan Bahan Organik-Inorganik (Dye-sensitized Solar Cell)", Institut Teknologi Bandung, Bandung. 
[4] http://solarsystem.nasa.gov/planets/profile.cfm (Diakses pada 25 Mei 2011).

[5] http://id.wikipedia.org/wiki/Kasturi (Diakses pada 8 Januari 2013).

[6] Supiyanti, Wiwin. dkk, (2010), "Uji Aktivitas Antioksidan Dan Penentuan Kandungan Antosianin Total Kulit buah kasturi (Garcinia Mangostana L.)", Sekolah Tinggi Ilmu Farmasi Yayasan Pharmasi, Semarang.

[7] http://www.rapidtables.com/calc/light/how-lux-to-lumen.htm

[8] http://www.rapidtables.com/calc/light/how-lumen-to-watt.htm.

[9] http://www.rapidtables.com/calc/light/lumen-to-watt-calculator.htm. 